\title{
ВОПРОСЫ РОССИЙСКО-МОНГОПЬСКИХ ОТНОШЕНИЙ В НАЧАЛЕ XX ВЕКА (1900-1921 ГГ.): ЭКОНОМИКА, ДИПЛОМАТИЯ, КУЛЬТУРА
}

\author{
А.П.Суходолов \\ Б.Болдбаатор * \\ Ю.В.Кузьмин \\ Д.Шурхуу*
}

\section{Краткий смысп:}

В статье показано развитие русско-монгольских отношений в первой четверти XX века, становление монгольского национального государства и роль России; представлена современная характеристика исследований данной проблемы в российской и монгольской историографии.

Ключевые спова: система международных отношений, русско-монгольские отношения, "монгольский вопрос", РоссияМонголия-Китай, историография, дипломатия, национальные интересы.

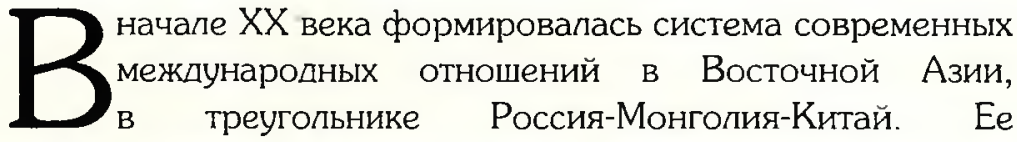
становпение и развитие происходипо в спожных исторических усповиях трансформации модепей попитического и социальноэкономического развития стран региона, перехода Цинского Китая к республиканской форме правления, становления монгольской нашиональной государственности с 1911 года и радикальных социальных изменений в России.

\footnotetext{
${ }^{*}$ Суходолов Александр Петрович - Өвөр Байгалийн эдийн засаг, эрх зүйн Упсын их сургуулийн I орпогч захирал, эдийн засгийн ухааны доктор, профессор.

"Базар Болдбаатар - Эдийн засгийн ухааны доктор, профессор

"Кузьмин Юрий Васильевич - Өвөр Байгапийн элийн засаг, эрх зүйн Упсын их сургуупийн дэлхийн эдийн засгийн тэнхмийн профессор

"Д.Шурхуу - ШУА-ийн Олон улс судлалын хүрээлэнгийн захирал, доктор, дэд професcop
} 


\section{Вопросы российско - монгольских отношений}

На рубеже X1X - XX веков Монголия, за сравнительно короткий исторический промежуток времени прошла несколько важных этапов внешнепопитического развития, сменила системы взаимоотношений с Китаем и Россий. До 1911г. Монголия входила в состав Цинской империи, это был завершаюший этап зависимого развития в юридических рамках другого государства. Монголия пользовалась широкой автономией, особенно на ее начальном этапе. Второй этап: 1911-1915 гг. Это время полного дистанцирования от Китая и сближения с Россией, фактической независимости Монголии при поддержке России. 1915 -1919 гг.- период Автономной Монголии. Формально и юридически Монголия является автономной частью республиканского Китая, фактически независимое государство. В рамках дипломатического треугольника Россия-Монголия-Китай соотношение сил и факторов впияния меняется.

На систему международных отношений в регионе впияли и отношения России с европейскими странами, США, Японией. Россия взяла на себя определенные обязательства в отношениях с Ангпией, Францией и Японией.

Россия и Великобритания также имепи ряд международных согпашений по разграничению сфер впияния в Азии. Они касапись разграничения на Ближнем Востоке и Восточной Азии.

Так, на внешнюю политику России в Монголии (Внешней и Внутренней) и Маньчжурии впияли русско-японские согпашения 1907, 1910, 1912 гг. Разграничение сфер впияния России и Японии в этом регионе влияли на позицию России в “монгольском вопросе".

Становление новой системы международных отношений и формирование новых границ происходило в спожных усповиях диппоматических переговоров межау Россией, Китаем и Монгопией и подписания ряда международных соглашений и договоров между странами (Русско-монгопьское соглашение 1912г., Русскокитайская декларачия 1913 г., Клхтинское соглашение 1915 г.). Наибопее спожный характер имепи переговоры о создании автономной Монголии и определении ее международного статуса. Русско-китайские противоречия 1911-1915 гг. наибопее остро проявились в "монгольском" и "урянхайском" вопросах. Объективные и взвешенные оценки дипломатической истории России и Монгопии имеют важнейшее значение дия развития современных двусторонних отношений. 


\section{Столетний юбилей исторических событий вызвали в Монгопии и России научный и обшественный интерес,} издание оригинальных исторических источников и проведение международных конференций, в которых по-разному оцениваются исторические события. Международные конференции в УланБаторе: "Новые подходы к истории взаимоотношений России и Монголии и их современное состояние" (2007г.), "Независимость Монголии и монголы"(2011г.), “Монгольско-русский договор 1912 г. и И.Я.Коростовец"(2012г.), в Иркутске: “Монгопия в ХХ веке. 1911-2011гг."(2011г.), в Упан-Удэ: “Россия-Монголия. Сто пет дипломатического сотрудничествам(2012г.)1. В данных усповиях российская историческая наука, российское монгоповедение должно более четко опредепить свою позицию и аргументированно ее обосновать и отстаивать.

Перемешение современного центра мировой экономики в регион Восточной Азии и Китай ведет к изменению геополитической ситуации в мире и регионе. Современный Китай преврашается в мирового экономического пидера и меняет характер и структуру экономических взаимоотношений в треугольнике Россия-Монголия-Китай. России для сохранения своих позиций в Монгопии необходимо не просто усилить попитическое и экономическое внимание к ближайшему соседу и партнеру, но и проводить системную и согласованную политику, усилить работу по совместному осмыслению и анализу истории российскомонгольских отношений.

Монголия занимает выгодное геополитическое попожение и явияется удобным "наблюдательным пунктом" в Северо-Восточной и Центрапьной Азии. Поэтому не спучаен интерес западных стран и США к Монгопии. В монгопьской периодической печати и заявпениях политиков США называют

"третьим соседом". Основатепьный анализ истории русскомонголо-китайских отношений в 1900-1921 гг. позволит пучше понять национальные интересы России и Монголии на современном этапе, выработать наиболее приемлемую модель современных взаимоотношений.

Проблема "национальных интересов", "обшественных интересов", "государственных интересов" в научной питературе России только начинает специально разрабатываться. Проблема национальных интересов во внешней попитике России - наименее исспедованная пробпема. Современными российскими постепенно 
преодолевают несколько прямолинейные догматические вопросы "интересов" во внешней попитике. Продопжительное время конструирование внешней попитики и ее практическая реапизация находились в руках правяшей элиты, очень узкого круга попитических деятепей.

В начале XX века в России формировались обшественные движения, политические партии и обшественное мнение, которые в различной степени, прямо ипи опосредованно впияли на формирование внешней политики страны. Поэтому процесс определения внешнепопитического приоритета, механизм принятия решений все бопее успожняется и носит противоречивый характер.

Формирование российско-монгольских отношений в России, монгольское направпение внешней политики происходило в спожных усповиях внутрипартийной борьбы, несогласованности действий разпичных ведомств Российской империи (Министерство иностранных дел, Военное министерство, Министерство финансов, российское консупьство в Урге, региональные сибирские органы управпения). Показ борьбы различных тенденций в формировании различных тенденций в формировании внешнеполитической пинии России по отнопению к Монгопии отражает заинтересованность различных социальных споев российского обшества, совпадение и разпичие их интересов, выявпяет не только социапьные, но и региональные (центральные и сибирские) экономические интересы ${ }^{2}$. Это позволит избежать категорических оценок роли России в Восточной Азии вообще и в Монголии в частности. Абсолютизация характеристики внешней политики на основании оценок отдепьных представитепей российских ведомств, влиявших на ее формирование, представпяется не корректным.

Интенсивные экономические и купьтурные связи Сибири и Монголииспособствовали серьезномуизучениюмонгольскогоязыка, торговых путей, бытового уклада и экономических потребностей монгольского обшества. Это формировало в сибирском обшестве и администрации собственные региональные интересы, отличные от общероссийских задач. Непосредственная близость к Монголии и необходимость быстрого и оперативного реагирования на вызовы и события в стране, требовали немедленного реагирования и оперативного вмешатепьства.

В современной российской и монгольской историограсрии к настояшему времени накоплен значительный материап по истории 


\section{А.П.Суходопов, Б.Бопдбаатор, Ю.В.Кузьмин, Д.Шурхуу}

русско-монгольского экономического сотрудничества и торговпи, научного и культурного взаимодействия двух стран и народов, научного изучения истории и купьтуры Монголии, но отсутствует обобшаюшая работа по истории дипломатических отношений в период 1900-1921 гг.

В российской историографии можно выделить три основных этапа исспедования данной проблемы: первый этап (1900-1917 гг.), второй (1917-1991), третий период (1991- по настояшее время). Первый этап исспедования совпадает со временем реапьных событий начала XX века, в историографию они вошли как работы, посвяшеннье "монгопьскому вопросу".

В советский период исспедования проблемы преобладала характеристика русско-монгольскихотношенийкакне равноправных взаимоотношений, внешняя политика России в начале XX века расценивапась как захватническая и колонизаторская. Оценки, высказанные в первый период изучения, не использовались и не привлекались к характеристике отношений. Концептуально исходипи от тезиса, что прогрессивная внешняя попитика формировалась только в советский период, а внешняя политика царской России оценивалась негативно и отрицатепьно. В советский период на его более позднем этапе стали преодолеваться подобные односторонние оценки.

На современном этапе исспедования проблемы русскомонгопо-китайских отношений получили новый толчок. Введение в оборот новых архивных материалов, исследование дискуссионных вопросов, утрата идеологического фактора позволили российским историкам показать более взвешенную и объективную картину отношений Россиии Монгопиивначале ХХ века. Сталиисследоваться ранее "закрытые" проблемы: урянхайский, баргинский, монгольский, тибетские вопросы, русско-китайские противоречия в 1911-1915 гг. Не все вопросы получили однозначное решение в российской исторнографии. Идет накопление значительного фактического материала, формируются новые подходы к оценке исторических событий, что создает предпосылки для создания современной концепции российско-монгопьских отношений.

В изучение русско-монгольских отношений начала ХХ века значитепьный вклал внеспи российские ученые: Е.М.Даревская, Б.В.Базаров, Е.А.Белов, Е.В.Бойкова, И.Я.Златкин, С.Г.Пузянин, А.П.Попов, Ш.Б.Чимитдоржиев, Т.Д.Скрынникова, А.В.Попов, Н.П.Шастина, С.А.Нацов, Д.Б.Упымжиев, Е.А.Бепов, М.И.Гопьман, 
А.С.Жепезняков, Н.Е.Елинархова, А.В.Старцев, А.А.Сизова, Ю.В.Кузьмин, В.Д.Дугаров., а также монгольские ученые Б.Пигуу, Э.Пунцаг, Ц.Пунцагноров, Ш.Сандаг, Б.Ширендыб, П.Жамсран, Б.Болдбаатар, 3. Понжид, О.Батсайхан, Н.Хишигт, Д.Шурхуу, Ц.Батбаяр, Ж. Болдбаатар, Ж. Урангуа и др.

Монгольские историки за поспедние 20 пет проделали копоссальную работу по исспедованию истории Монгопии и русско-монгольских отношений в начале XX века. Продопжали свои исспедования известные историки Б.Ширендыб, П.Жамсран, Ц.Пунцагноров, С.Пурэвжав, С.Дамдинсурэн, Б.Бапдо, Ш.Нацагдорж, П.Хайсандай.

Значительный вклад внеспи историки Ж.Бопдбатаар, Ч.Дашдаваа, 3.Понжид, О.Батсайхан, Ц.Батбаяр, Ж.Урангуа, Н.Хишигт, Д.Шурхуу, К.Дэмбэрэл, и др. Особенно можно выдепить следуюшие монографии: Ж.Урангуа "Монголия в начале XX века"(2006), "Установпение независимости Монгопии и царская Россия"(2008), 3.Понжида “История финансовой системы Монголии (1911-1921)"(2006), Ж.Болдбатаара "Деятепи монгольской революции 1911 г."(2011), О.Батсайхана "Установление независимости Монгопии и Кяхтинский трехсторонний китайскорусско-монгольский договор" (1911-1916)"(2002), "Монголия по пути государства-нации.(1911-1946)"(2005), К.Дэмбэрэла "Международная среда и государственное развитие Монголии: сравнитепьный анализ в историческом контексте»(1998). Ц.Батбаяра "Монголия и Япония в первой половине XX века"(2002), "Монгопия и вепикие державы в первой половине XX векам(2006) ${ }^{3}$.

Необходимо выдепить вклад известного историкамонгоповеда Ш.Б. Чимитдоржиева "Россия и Монгопия (1987), Е.М.Даревской "Сибирь и Монголия"(1994), Н.Е.Единарховой "Русские в Монгопии. Основные этапы и формы экономической деятельности (1861-1921)»(2003), Е.А.Белова “Россия и Китай в начале ХХв. Российско-китайские противоречия»(1999), "Россия и Монголия"(1999), А.В.Старцева "Русская торговля в Монголии"(2003), Ю.В.Кузьмина "Монголия и монгольский вопрос" $(1997)^{4}$.

Российское китаеведение продепало грандиозную работу по описанию, обобщению и анализу российскокитайских отношений (В.С.Мясников, Е.А.Бепов, В.А.Моисеев, М.И.Спадковский, А.Н.Хохлов, В.Г.Дацышен и цр.). Крупные монографии В.С.Мясникова "Договорными статьями утвердили. 
Дипломатическая история русско-китайской границы ХУПХХ вв."(1996), В.А.Моисеева "Россия и Китай в Центральной Азии: вторая половина X1X -1917 г." (2003), С.Г.Пузянина "Россия-Монгопия-Китай в первой поповине XX в. Политиеские взаимоотношения в 1911-1949 гг."(2000), В.Г.Дашышена "Очерки истории российско-китайской границы во 2-й половине $\mathrm{X} 1 \mathrm{X}$ начале XX вв.»(2000), "История российско-китайских отношений в конце X1X - начале XX в.»(2000), Е.А.Бепова "Россия и Китай в начале XX в. Русско-китайские противоречия в 1911-1915 гг.»(1997) создали прочную научную основу для изучения истории русско-монгольских отношений ${ }^{5}$.

Сделана успешная попытка российских китаеведов создать обобшаюшую коппективную работу по истории русско-китайских отношений "Россия и Китай: четыре века взаимодействия"(2013). Китаеведение имеет большой творческий потенциал и несколько опережает другие сферы российского востоковедения. Заспуживает внимания стремление авторов создать полную и объективную картину событий и не формировать у читатепей определенный взгляд на события. Авторы отдепьных глав излагают собственные взгляды на описываемые события, не избегая спорных вопросов в питературе.

Опредепенный вклад в исспедование темы вносят историки, занимающиеся историей Сибири, историей Бурятии и Забайкалья, Тывы (История Тувы" в 2-х томах, “История Бурятии" в 3-х томах (2011г.), "Энциклопедия Забайкалья" в 4-х томах), “Историческая энциклопедия Сибири" (т.1-Ш)(2009). История пограничных территорий, биографии политических и пограничных деятепей, экономические связи территорий дополняют историю российскомонгольских отношений в начале XX века. Значитепьное место в отношениях данного периода занимали религиозные связи монголов, бурят, тувинцев. Паломничество российских ламаистов в Монголию и Тибет, приезд буддийских деятепей из Монгопии и Тибета в Россию находят отражение у российских исспедоватепей. Формированием художественных коллекций в России занимаются российские искусствоведы и музееведы.

Отдельное направление в России составляет история изучения российского монгоповедения, история его центров в Москве, Петербурге, Казани, Эписте, Улан-Удэ и Иркутске. Полной картины изучения истории и традиционной культуры Монгопии в России вообше и его чентров, к сожалению, до сих пор не 
создано. Обзорные статьи не отражают особенности и специфику отдепьных шкоп монгоповедения в России.

Заспуживают внимания исспедователей не только работы монголоведов, но и работы российских путешественников, военных, краеведов, купцов, журнапистов, студентов, которые содержат оригинальные оценки и характеристики русскомонгольских отношений и перспектив их развития. “Монгольский вопрос" обсуждался в государственных и обшественных структурах России, имел отражение в периодической печати страны, как центральной, так и сибирской прессе. Роль России и русскомонгольских отношений в монгольской прессе и публицистике является малоизученным в монгоповедении. Надеемся, что это "бепое пятно" со временем будет стерто.

Поспеднее двадцатилетие исторические школы России и Монголии развиваются нескопько обособленно, уровень изученности истории Монголии и русско-монгольских отношений в на́чале XX века двух странах сушественно различаются. Нет полной информированности сторон по изучаемой проблеме. Назрепа необходимость объединения совместных усилий по созданию обобшаюшей работы, что позвопит подвести итоги изученности темы и наметить пути разрешения спожных проблем.

Российские и монгопьские историки сделапи первые попытки предложить новую концепцию современной истории Монголии и российско-монгольских отношений в первой четверти XX века. Об этом свидетельствуют коппективные работы: "История Востока" в 6 томах, многотомная "История Монголии", "История Монголии. XX век» (2007), "Россия и Монголия. Новый взгляд на историю взаимоотношений в XX веке» (2001)6, “Россия и Восток"(2001).

Серьезную попытку проанализировать российско-китайские отношения предприняпи российские китаеведы. Вышел в свет солидный труд известных российских ученых-китаеведов "Россия и Китай. Четыре века взаимодействиям(2013)7. Обший подход к оченке русско-китайских отношений полезен для изучения русскомонгольских отношений.

Назрела необходимость создания совместной российскомонгольской обобшаюшей работы по истории российскомонгольских отношений в первой четверти ХХ века, с привлечением специалистов разпичного профиля: историков, экономистов, филологов, философов, политологов, культуропогов ${ }^{8}$. Это позволит создать объемную и всестороннюю историю взаимоотношений двух 
стран, народов и купьтур. Результаты исспедования необходимо ввести в научный оборот на русском, монгольском и английском языках. Это позволит стать ближе и понятнее монгопьской исторической науке и мировому монголоведению.

Публикация новых оригинальных исторических источников в Монгопии и России, появпение новых подходов и оценок в российской и монгольской историографии диктуют опредепение спорных точек зрения, уточнение исторических характеристик и создание цепьнй картины отношений двух стран.

Поспедние годы отмечены выходом челого ряда сборников документов по истории российско-монгольских отношений и международных отношений в регионе: "Российско-монгольское военное сотрудничество. 1911-1946 гг.", "За три века. Тувинскорусско-монгольско-китайские отношения (1615-1915). Архивные документы»(1995 г.), “Россия и Тува - вместе 60 пет. Сб. арх. Документов."(2004), «Россия и Тибет. Сборник русских архивных документов. 1900-1914."(2005г.), “Собрание архивных документов по истории Тувы. Том П (1911-1921) (2011г.)9. Создана солидная документальная база дия создания новой комплексной работы по истории российско-монгольских отношений в первой четверти ХХ века.

Опубликованы оригинальные мемуары: И.Я.Коростовец "Девять месяцев в Монголии", Д.П.Першин "Барон Унгерн, Урга и Алтан-Булаг»(1999), П.А.Бадмаев. "За кулисами царизма: Воспоминания. Мемуары.»(2001), И.И.Серебренникова "Мои воспоминания". Вместе с ранее опубликованными мемуарами С.Ю.Витте, В.Н.Коковцева, С.Д.Сазонова, И.И.Попова, они позвопяют более многомерно показать позицию России в решении "монгольского вопроса".

Наличие и выявпение новых оригинальных архивных и мемуарньх источников, междисциплинарный подход к проблеме, уточнение подходов к теме российских и монгопьских ученых позвопяют формирование новой концепции исторического развития Монголии и русско-монгопьских отношений в 1900-1921 гг.

Концептуально исходим из положения анапиза конкретноисторического материала по истории русско-монгопьских отношений начала XX века с позиции национальных интересов страны. У'читываем многообразие всех факторов, формируюших определение направлений внешней политики, всех государственных организаций страны, участвуюших в ее создании. 
Проблемы, требуюшие дополнительного и специального исспедования:

1.Специального исследования заспуживают вопросы историографии и источниковедения истории русско-монгольских отношений. Российские источники являются основой исспедований не только в России, но и в Монголии, Китае и в западных, восточных странах. Необходима пубпикация наиболее оригинальных документов из центральных и регионапьных архивов России и Монгопии.

2. Пробпема национапьных интересов России в Монгопии: геополитические, экономические и военные. Проблема экономической, политической, дипломатической и военной заинтересованности Монголии в подлержке России.

3. Роль российских военных в становлении независимости Монголии. Биографии наиболее известных военных исследователей и практических деятепей. Ропь и значение создания современной армии Монголии. Ввод российских войск в Монголию и их роль в зашите самостоятепьности страны.

4. Оценка уровня экономического развития Монголии и характеристика монгопьской модепи экономического развития. Трапиционная экономика и новые явления в экономике в начале ХХ века. Роль внешнего экономического и финансового фактора.

5.Специального исспедования заспуживает русскомонгольская торговля. Выявление, анализ и обобшение статистических данных по размерам русско-монгольской торговли 1900-1921 гг. Разпичие точек зрения в источниках и литературе по данной проблеме, отсутствие сводных данных по динамике российско-монгольской торговли.

6. Позитивные инегативные черты деятепьности иностранного капитала в Монголии. Поспедствия деятепьности торгового капитала из Китая, России и западных стран.

7.Отсутствует обобшаюшая работа по транспортной инсраструктуре русско-монгольской торговли, разработке проектов железных дорог в Монголию.

8. В российской историографии спабо исследован вопрос о позиции запалных стран по "монгольскому вопросу".

9. Китайская историография "монгольского вопроса".

10. Монголо-тибетские отношения и договор 1913 г., влияние на внешнюю политику России.

11. Ропь японского фактора в российско-монгольских 
отношениях. Роль русско-японских секретных соглашений 1907 , 1910, 1912 гг.

12. Взвешеннойиобъективнойоценкиисториковзаспуживают некоторые пичности в русско-монгопьских отношениях (Джа-Пама, Тохтохо-тайцжи, барон Унгерн, П.А.Бадмаев и др.).

Материалы и результаты данного исспедования могут быть использованы при разработке и публикации колпективных обобшаюших работ по истории Монголии и российско-монгольских отношений в XX веке, а также учебных пособий и спецкурсов по истории и экономике стран Северо-Восточной Азии, современной историографии стран Востока. Обработанный материал может быть использован при публикации сборников документов по истории Монгопии, русско-монгольских отношений, истории Бурятии и Тувы, истории международных отношений и российского монголоведения.

Практическое значение данного исследования связано с возможностыю составления практических рекомендаций для действуюших органов Российской Федерации, и ее региональных образований, связанных с Монголией, которые позволят понять динамику развития российско-монгольских отношений, истоки и причины противоречий и трудностей отношений двух соседних стран, составить научные прогнозы развития отношений. Опредепить особенности развития обшественно-попитической мыспи и ее влияния на выработку практических решений, повысить эффективность международной политики страны и зашитить ее национальные интересы.

\section{СПНСОК ИСПОПЬЗОВАННОЙ ПИТЕРАТУРЫ}

1 Монголия в ХХ веке. 1911-2011 гг.- Иркутск, 2011; Независимость Монголии и монгопы.- Упан-Батор, 2011; Россия-Монголия. Сто пет диппоматического сотрудничества. - Упан-Удэ, 2012.

2 Кузьмин Ю.В. Монголия и "монгольский вопрос" в общественно-политической мыспи России. - Иркутск, 1997

3 Батсайхан О. Установление независимости Монголии и Кяхтинский китайско-русско-монгольский договор. 19111916 гг. - Упан-Батор, 2002; Батбаяр Ц. Монголия и Япония в первой поповине XX века. - Улан-Батор, 2002. Батбаяр Ц. Монгол ба их гурнууд ХХ зууны эхний хагаст (Монголия и вепикие державы в первой половине ХХ века).- Упан-Батор, 
2006.

${ }^{4}$ Даревская Е.М. Сибирь и Монгопия. - Иркутск, 1994; Белов Е.А. Россия и Монгопия.- М., 1999; Старцев А.В. Русская торговля в Монголии.- Барнаул, 2003.

${ }^{5}$ Мясников В.С.Договорными статьями утвердили. Дипломатическая история русско - китайской гранишы 17-20 вв.- M., 1996

${ }^{6}$ Россия и Монгопия. Новый взгляд на историю взаимоотношений в XX веке.- М.,2001

7 Россия и Китай. Четыре века взаимодействия. - М.,2013.

8 Актуальные вопросы истории российско - монгольских отношений первой четверти XX века: сб. научн. тр. -Иркутск: Изд - во БГУЭП, 2013;

Россия и Монгопия на рубеже X1X - XX веков: экономика, дипломатия, культура: сб. научн. тр. - Упан-Батор; Иркутск: Изд-во БГУЭП, 2013.

${ }^{9}$ Собрание архивных документов по истории Тувы. Том П (1911-1921 гг.). - Улан - Батор, 2011.

Abstract: The development of Russian-Mongolian relations in the first quarter of XX century, formation of the Mongolian national state ant the role of Russia in this process are mentioned in this article; the modern characteristic of researches of these problems in Russian and Mongolian historiography is also presented.

Keywords: System of international relations, Russian-Mongolian relations, "Mongolian question", Russia-Mongolia-China, historiography, diplomacy, national interests. 